\title{
INVESTIGATING A CORRELATION BETWEEN THE LEVELS OF PERIPHERAL BLOOD CYTOKINES AND THE RISK FOR CARDIOVASCULAR COMPLICATIONS IN PATIENTS WITH STAGE II ESSENTIAL HYPERTENSION
}

Radaeva $\mathrm{OA}^{1} \otimes$, Simbirtsev $\mathrm{AS}^{2}$

National Research Mordovia State University, Saransk, Russia

2 State Research Institute of Highly Pure Biopreparations, FMBA, St. Petersburg, Russia

\begin{abstract}
Essential hypertension $(\mathrm{EH})$ is one of the most common modifiable risk factors for cardiovascular diseases and death. The aim of this study was to investigate a correlation between the levels of some cytokines (interleukins, adhesion molecules, tumor necrosis and growth factors, etc.) in the peripheral blood of patients with stage II EH and the rate of complications (myocardial infarction, acute cerebrovascular events, and transient ischemic attacks) occurring in a 5-year follow-up period. Twenty-eight cytokines were measured using ELISA, including IL1 $\beta$, IL1 $\alpha$, IL1ra, IL18, IL18BP, IL37, IL6, sIL6r, LIF, sLIFr, IGF-1, IGFBP-1, TNF $\alpha$, sTNF-RI, sVCAM-1, IL17, IL2, IL4, IL10, TGF-ß1, IL8, CX3CL1, CXCL10, INFy, M-CSF, IL34, VEGF-A, and erythropoietin, and a few vasoactive peptides, including NO, iNOS, eNOS, ADMA, SDMA, Nt-proCNP, and Nt-proBNP, in the peripheral blood samples of 200 patients with stage II EH who had been suffering from this condition for 10 to 14 years and were receiving comparable therapies to bring their blood pressure down. The patients were followed up for 5 years to keep track of complications. The retrospective analysis revealed that the group of patients who developed complications during the 5-year follow-up period exhibited a decline in the levels of IL1ra $(p<0.001)$ and IL10 $(p<0.001)$ and a rise in IL1 $\beta(p<0.001)$, TNF $\alpha(p<0.001)$ and M-CSF $(p<0.001)$ in comparison with the group of those who did not develop any complications. The multivariate Cox regression analysis was applied to the following parameters: IL $1 \beta>18.8 \mathrm{pg} / \mathrm{ml} ; \mathrm{IL} 1 \mathrm{ra}<511 \mathrm{pg} / \mathrm{ml}$; IL6 $>23.8 \mathrm{pg} / \mathrm{ml}$;

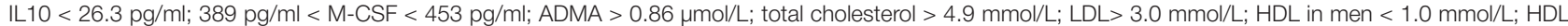
in women $<1.2 \mathrm{mmol} / \mathrm{L}$. The analysis revealed that $\mathrm{M}-\mathrm{CSF}$ in the range from 389 to $453 \mathrm{pg} / \mathrm{ml}(p<0.001)$ and LDL above $3.0 \mathrm{mmol} / \mathrm{L}(p<0.01)$ correlated with an increase in the risk for end-organ damage in stage II EH. Changes in the cytokine levels can be regarded as a predictor of myocardial and cerebral damage in patients with stage II EH. Measurement of peripheral blood M-CSF can be included into the classic risk assessment schemes for the cardiovascular complications in the studied cohort of patients.
\end{abstract}

Keywords: cytokines, essential hypertension, myocardial infarction, stroke, M-CSF

Author contribution: Radaeva OA recruited patients, collected blood samples for the study took medical histories, interpreted the study results, and wrote the manuscript. Simbirtsev AS conceived and planned the study, analyzed the obtained data and revised the manuscript.

Compliance with ethical standards: the study was approved by the Ethics Committee of Ogariov Mordovian State University (Protocol 12 dated December 12 , 2008). All patients gave their informed consent to participate. Blood samples were collected in full compliance with the Declaration of Helsinki (2000) and the Protocol of the Convention on Human Rights and Biomedicine of the Council of Europe (1999).

$\triangle$ Correspondence should be addressed: Olga A. Radaeva

Ulianova 26/a, Saransk, 430030; vtlbwbyf_79@mail.ru

Received: 16.07.2018 Accepted: 27.02.2019 Published online: 06.03.2019

DOI: $10.24075 / \mathrm{brsmu} .2019 .006$

\section{АНАЛИЗ КОРРЕЛЯЦИИ СОДЕРЖАНИЯ ЦИТОКИНОВ ПЕРИФЕРИЧЕСКОЙ КРОВИ С РИСКОМ РАЗВИТИЯ СЕРДЕЧНО-СОСУДИСТЫХ ОСЛОЖНЕНИЙ У БОЛЬНЫХ ЭССЕНЦИАЛЬНОЙ АРТЕРИАЛЬНОЙ ГИПЕРТЕНЗИЕЙ ІІ СТАДИИ}

О. А. Радаева ${ }^{1}$, А. С. Симбирцев²

${ }^{1}$ Мордовский государственный университет имени Н. П. Огарева, Саранск, Россия

2 Государственный научно-исследовательский институт особо чистых биопрепаратов Федерального медико-биологического агентства, Санкт-Петербург, Россия

Эссенциальная артериальная гипертензия (ЭАГ) остается наиболее распространенным модисицируемым фактором риска сердечно-сосудистых заболеваний и смерти. Целью исследования было выявить корреляцию содержания цитокинов (интерлейкинов, молекул адгезии, факторов некроза опухоли, роста и др.) в сыворотке периферической крови и частоты осложнений (инфаркта миокарда, острого нарушения мозгового кровообращения) в последующие 5 лет у больных ЭАГ ІІ стадии. У 200 пациентов с ЭАГ ІІ стадии с длительностью заболевания 10-14 лет, получавших сопоставимую гипотензивную терапию и показавших целевые уровни АД, с помощью ИФА в сыворотке периферической крови определяли содержание 28 цитокинов (IL1 $\beta$, IL1 $\alpha$, IL1ra, IL18, IL18BP, IL37, IL6, sIL6r, LIF, sLIFr, IGF-1, IGFBP-1, TNF $\alpha$, sTNF-RI, sVCAM-1, IL17, IL2, IL4, IL10, TGF- $\beta 1$, IL8, CX3CL1, CXCL10, INFy, M-CSF, IL34, VEGF-A, эритропоэтина) и вазоактивных пептидов (NO, iNOS, eNOS, ADMA, SDMA, Nt-proCNP, Nt-proBNP). B течение последующих 5 лет фиксировали случаи развития осложнений. Ретроспективный анализ показал, что для группы с развитием осложнений в последующие 5 лет характерно предварительное снижение уровней IL1ra $(p<0,001)$ и IL10 ( $p<0,001)$ на фоне повышения содержания IL1 $(p<0,001)$, TNFa (p < 0,001) и M-CSF ( $<<0,001)$ в сыворотке крови при сравнении с группой без осложнений. Многофакторный анализ с включением в регрессионную модель Кокса ряда показателей: IL1ß > 18,8 пг/мл; IL1ra < 511 пг/мл; IL6 > 23,8 пг/мл; IL10 < 26,3 пг/мл; 389 пг/мл < M-CSF < 453 пг/мл; ADMA > 0,86 мкмоль/л; общий холестерин > 4,9 ммоль/л; ЛПНП > 3,0 ммоль/л; ЛПВП у мужчин < 1,0 ммоль/л; у женщин < 1,2 ммоль/л выявил независимый характер «Влияния» на повышение частоты повреждения органов-мишеней при ЭАГ ॥ стадии следующих показателей: содержания M-CSF в диапазоне 389-453 пг/мл ( $p<0,001)$, а также уровня ЛПНП более 3,0 ммоль/л ( $p<0,01)$. Изменение уровня цитокинов является патогенетически обоснованным предиктором повреждения миокарда и головного мозга у больных ЭАГ II стадии, а определение уровня M-CSF в крови может дополнить классические схемы расчета риска развития сердечно-сосудистых осложнений у данной категории больных

Ключевые слова: цитокины, эссенциальная артериальная гипертензия, инфаркт миокарда, острое нарушение мозгового кровообращения, колониестимулирующий фактор макрофагов M-CSF

Информация о вкладе авторов: О. А. Радаева - набор группы пациентов, забор материала для исследования, сбор данных, интерпретация результатов исследования, написание и компьютерная подготовка рукописи; А. С. Симбирцев - планирование и разработка методологии исследования, анализ данных, редактирование текста

Соблюдение этических стандартов: исследование одобрено этическим комитетом МГУ им. Н. П. Огарева (протокол № 12 от 14 декабря 2008 ); все пациенты подписали добровольное информированное согласие; получение биологического материала для исследования (кровь) производили с учетом положений Хельсинской декларации ВМА (2000) и протокола Конвенции Совета Европы о правах человека и биомедицине (1999).

Для корреспонденции: Ольга Александровна Радаева ул. Ульянова, д. 26а, г. Саранск, 430030; vtlbwbyf_79@mail.ru

Статья получена: 16.07.2018 Статья принята к печати: 27.02.2019 Опубликована онлайн: 06.03.2019

DOI: $10.24075 /$ vrgmu.2019.006 
Essential hypertension $(E H)$ is one of the most common modifiable risk factors for cardiovascular diseases and death. According to some estimates, more than 1 billion adults suffer from $\mathrm{EH}$. Their number is expected to have reached 1.5 billion in 2025 [1]. It was long thought that end-organ damage resulted from the increased hydrostatic pressure against blood vessel walls. However, recently a few research studies have been conducted [2-10] into the cytokine pathways in $\mathrm{EH}$ complications, including myocardial infarction (MI), acute cerebrovascular events (ACVE), and transient ischemic attacks (TIA), that pose a significant risk of death and morbidity to the working-age population. It is hardly disputable that end-organ damage is the ultimate sequela of chronic inflammation in the presence of elevated blood pressure and atherosclerosis. However, it is still unclear whether certain cytokines have a prognostic potential in the assessment of long-term risks for cardiovascular disorders in patients with stage II EH. The aim of this study was to investigate a correlation between peripheral blood concentrations of some cytokines in patients with stage II EH and the rate of cardiovascular complications (MI, ACVE, TIA) developed during the 5-year observation period.

\section{METHODS}

The study was carried out at the facilities of the Regional Vascular Center of Mordovian Republican Clinical Hospital No. 4, Mordovian Republican Clinical Hospital No. 3 and the Department of Immunology, Microbiology and Virology of Ogariov Mordovian State University in 2013 through 2018. The study recruited 490 participants with stage II EH. Of them, 200 patients were prescribed comparable antihypertensive therapies and then followed up for 5 years. Among them were 100 females and 100 males with the mean age of $57.5 \pm 1.2$ years at the beginning of the study.

The following inclusion criteria were applied: stage ॥ EH lasting for 10-14 years; working age (females under 60, males under 65); comparable treatment regimens prescribed (monotherapy with ACE inhibitors or ACEls+ diuretics); informed consent to participate. Patients with comorbidities, type I diabetes mellitus, metabolic syndrome, allergies, autoimmune conditions, secondary hypertension, infections or mental health problems 1 month before the study, alcoholism/drug abuse, and those who refused to participate were excluded from the study. The following cytokines were measured in the peripheral blood samples of 100 female and 100 male patients with stage II EH in order to assess their potential in predicting longterm cardiovascular complications (MI and ACVE): IL1 $\beta$, IL1 $\alpha$, IL1ra, IL18, IL18BP, IL37, IL6, sIL6r, LIF, sLIFr, IGF-1, IGFBP-1, TNFa, sTNF-RI, sVCAM-1, IL17, IL2, IL4, IL10, TGF- $\beta 1$, IL8, CX3CL1, CXCL10, INFy, M-CSF, IL34, VEGF-A, erythropoietin, and a group of vasoactive peptides including $\mathrm{NO}$, iNOS, eNOS, ADMA, SDMA, Nt-proCNP, and Nt-proBNP. These proteins were selected because they are either synthetized by vascular cells or the end organs have receptors recognizing the listed cytokines. Their concentrations were determined using immunoassays. In the 5-year follow-up period, the patients were surveyed on the phone using the original questionnaire; complications (MY, ACVE, TIA) were noted down and later correlated to the patients' medical records.

The obtained data were processed in Statistica 8.0 (StatSoft; ver 8.0). Normality of data distribution was tested using the one-sample Kolmogorov-Smirnoff test. In this article, the data are presented as an arithmetic mean (M), a standard deviation (SD) and 95\% confidence interval for the mean $(95 \% \mathrm{Cl})$ for normal distribution. Student's t-test was used to compare the main groups. Absolute and relative risks of endorgan damage (MI, ACVE, TIA) were computed, as well as 95\% $\mathrm{Cl}$ for sensitivity (Se) and specificity (Sp). Uni- and multivariate Cox regressions were calculated.

\section{RESULTS}

We correlated the levels of IL1 $\beta, I L 1 \alpha, I L 1 r a, I L 37, I L 18$, IL18BP, IL6, sIL6r, LIF, sLIFr, TNF $\alpha$, sTNF-RI, sVCAM, IL2, IL8, IL4, IL10, IFNy, IGF-1, IGFBP-1, M-CSF, IL34, VEGF-A, CX3CL1, CXCL10, TGFß1, IL17A, and erythropoietin in the peripheral blood of 200 patients in treatment for stage II EH who had been suffering from the condition for 10-14 years to the development of cardiovascular complications during the 5 -year follow-up period. The retrospective analysis revealed a decline in IL1ra $(p<0.001)$ and IL10 $(p<0.001)$ concentrations and a rise in IL1 $\beta$ ( $p<0.001)$, TNF $\alpha(p<0.001)$, and M-CSF $(p<0.001)$ levels in the group of 47 patients who developed cardiovascular complications in the follow-up period, including MI (20 patients), ACVE (14 patients) and TIA (13 patients), as compared to the group of patients who did no develop any long-term complications during the study (Table 1). No significant differences were observed in the average values of other parameters between the groups of patients with and without complications $(p>0.05)$.

Further analysis of interquartile ranges for the patients with EH who developed complications after 6-10 years of observation demonstrated (Table 2) that at IL $1 \mathrm{ra}<513 \mathrm{pg} / \mathrm{ml}$, the rate of complications over those 5 years increased 2.24 times $(p<0.05)$ reaching $45 \%$ (Sp was $83 \%$, Se was $41.7 \%)$, $\chi^{2}=5.25(p<0.05), C=0,33$ (a moderate correlation); at $\mathrm{IL} 10<26.3 \mathrm{pg} / \mathrm{ml}$ the risk grew 1.94 times $(\mathrm{p}<0.05)$, reaching $31 \%$ (Sp 54.9\%, Se 66\%), $\chi^{2}=6.26$ ( $\left.p<0.05\right), C=0.17(a$ weak correlation); at IL $1 \beta>18.7 \mathrm{pg} / \mathrm{ml}$ the risk increased 2.37 times $(p<0.05)$ reaching 38\% (Sp 59\%, Se 80\%), $\chi^{2}=7.59$ ( $p<0.05), C=0.22$ (a moderate correlation); at IL6 > 23.8 the risk grew 1.76 times $(p<0.05)$ reaching 30\% (Sp 54\%, Se 63.8\%), $\chi^{2}=6.45$ ( $p<0.05$ ), $C=0.17$ (a weak correlation). At M-CSF concentrations in the blood serum ranging from 389 to $453 \mathrm{pg} / \mathrm{ml}$ the risk of cardiovascular complications in year 5 and in the next 5 years grew 3.87 -fold $(p<0.001)$, as compared to M-CSF concentrations < $389 \mathrm{pg} / \mathrm{ml}$ and $>$ $453 \mathrm{pg} / \mathrm{ml}$, reaching 62\% (Sp 81.6\%, Se 66\%), $\chi^{2}=32.5$ ( $p<0.001$ ), $C=0.6$ (a relatively strong correlation). M-CSF was the most significant risk predictor in comparison with other cytokines. The analysis of interquartile ranges for the patients who developed cardiovascular complications in years 6-10 of the observation did not reveal any significant correlations between TNF $\alpha$ concentrations measured in year 5 and the analyzed risks.

The univariate Cox regression analysis confirmed a reliable correlation between the changes in the peripheral blood cytokine concentrations in patients with stage II EH (IL1 $\beta>$ $18.8 \mathrm{pg} / \mathrm{ml}$; IL1 $\mathrm{ra}<511 \mathrm{pg} / \mathrm{ml}$; IL6 > $23.8 \mathrm{pg} / \mathrm{ml}$; IL $10<26.3 \mathrm{pg} / \mathrm{ml}$; $389 \mathrm{pg} / \mathrm{ml}<\mathrm{M}-\mathrm{CSF}<453 \mathrm{pg} / \mathrm{ml}$ ) and the risk of cardiovascular disorders during the observation period (Table 3 ).

The analysis of relationships between all studied parameters and vasoactive peptides (Tables 4,5 ) demonstrated that cytokines that could be regarded as potential long-term predictors of cardiovascular complications in patients with stage II $\mathrm{EH}$, namely IL1ra, IL10, IL1 $\beta$, TNF $\alpha$, and M-CSF, correlate with the serum levels of asymmetric dimethylarginine (ADMA), a vasoactive peptide. Therefore, when building the pathogenic model, we added ADMA to the list of variables subjected to the multivariate regression analysis to assess the independence of 
the revealed risk factors. This has a pathogenic significance and affects the diagnostic and clinical value of the recorded changes. M-CSF concentrations in the blood serum of patients with stage II EH have the strongest correlation with ADMA. The model subjected to the multivariate analysis also included classic risk factors as recommended by the international and Russian guidelines for the risk assessment of complications in patients with hypertension. Based on the results yielded by the multivariate analysis, increased rates of end-organ damage in patients with stage II EH reported during the 5-year observation period correlated with M-CSF levels in the range between 389 and $453 \mathrm{pg} / \mathrm{ml}(p<0.001)$ regardless of patients' sex, as well as with the classic risk factor: LDP $>3.0 \mathrm{mmol} / \mathrm{L}(p<0.01)$ (Table 6).

\section{DISCUSSION}

Significant correlations have been reported between $\mathrm{EH}$ complications, including ACVE and $\mathrm{MI}$, and the peripheral blood concentrations of IL17, IFNy, TNFa, IL6 [2, 11], sTNF-
RI [9], IL1 [12, 13], CXC chemokines [6], LIF [14], IL12 [15], and other cytokines. However, there have been few longitudinal studies of this problem, and only a small range of cytokines has been analyzed. Considering that the literature on the role of cytokines in the pathogenesis of $\mathrm{EH}$ is scarce, it is important to study the dynamics of these immunoregulatory factors in patients who develop EH complications and to identify factors that maintain their statistical and pathogenic significance when other cytokines or classic risk factors are introduced into the pathogenic model. We have found that changes in IL1ra, IL10, IL1 $\beta$, IL6, and M-CSF levels correlate with the development of complications (MI, ACVE, TIA) during a 5-year period. In our study, the increase in the concentrations of anti-inflammatory IL1ra and IL10 correlated with a lower number of complications. Correlations between other analyzed cytokines and the risk for EH complications were not observed. Out findings are not fully consistent with the literature reporting correlations between $\mathrm{LIF}, \mathrm{IL} 1 \alpha$, etc. and the risk for developing $\mathrm{EH}$ complications $[10,14]$. This could be due to different inclusion criteria applied in different studies (the sex ratio, age, antihypertensive

Table 1. Cytokine levels in patients in treatment for stage II EH who developed cardiovascular complications during the 5-year follow-up period and those who did not have any complications. $\mathrm{M}(\sigma)$

\begin{tabular}{|c|c|c|}
\hline $\begin{array}{l}\text { Cytokine levels } \\
(\mathrm{pg} / \mathrm{ml})\end{array}$ & $\begin{array}{l}\text { Patients without complications } \\
\qquad n=153\end{array}$ & $\begin{array}{l}\text { Patinates with EH and complications } \\
\qquad n=47\end{array}$ \\
\hline IL1 $\beta$ & $14.2(4.42)$ & $21.3(3.32)^{\star \text { no complications }}$ \\
\hline IL1 1 (f) & $12.6(3.21)$ & $13.2(2.91)$ \\
\hline IL1ra & $650(112)$ & $496(93)^{\text {*no complications }}$ \\
\hline IL18 & $360(64)$ & $393(87)$ \\
\hline IL18BP & $6790(1170)$ & $6440(1620)$ \\
\hline IL6 & $21.7(4.94)$ & $24.9(4.41)^{\wedge \text { no complications }}$ \\
\hline sIL6r & $1889(323)$ & $1733(312)$ \\
\hline TNF $\alpha$ & $20.2(4.47)$ & $26.6(4.5)^{\star \text { no complications }}$ \\
\hline sTNF-RI & $2598(680)$ & 2873 (699) \\
\hline sVCAM-1 & 577 (101) & $591(90)$ \\
\hline IL2 & $10.6(3.16)$ & $10.9(3.02)$ \\
\hline IL8 & $28.7(6.74)$ & $30.6(7.16)$ \\
\hline IL4 & $19.8(4.11)$ & $20.8(4.05)$ \\
\hline IL10 & $29.3(6.99)$ & $23.8(7.17)^{\star \text { no complications }}$ \\
\hline IFNy & $18.4(4.18)$ & $18.1(4.39)$ \\
\hline IL37 & $93.2(26.9)$ & $90.1(24.2)$ \\
\hline IL17A & $2.5(0.56)$ & $2.46(0.49)$ \\
\hline LIF (females) & $7.28(2.78)$ & $7.76(2.63)$ \\
\hline sLIFr (females) & 40500 (1120) & $42100(1600)$ \\
\hline IGF-1 & 116000 (32300) & 122000 (30800) \\
\hline M-CSF & $352(88)$ & $456(69)^{\text {×no complications }}$ \\
\hline IL34 & $133(40)$ & $137(36)$ \\
\hline VEGF-A & 339 (101) & 344 (95) \\
\hline CX3CL1 & $510(105)$ & $542(120)$ \\
\hline CXCL10 & $17.8(4.33)$ & $18.9(3.92)$ \\
\hline TGF $\beta 1$ & $21.8(4.57)$ & $22.1(4.24)$ \\
\hline Neopterin & $8.81(3.19)$ & $8.23(2.8)$ \\
\hline Erythropoietin & $11.4(3.64)$ & $16.6(3.12)^{\star \text { no complications }}$ \\
\hline
\end{tabular}

Note: ${ }^{\wedge}-p<0.01{ }^{*}-p<0.001$ in comparison with patients without complications reported in the 5-year follow-up period. 
treatment, normalized blood pressure, etc) and indicates the high significance of the observational group homogeneity, which affects the pathogenic significance of the obtained data. Importantly, our study shows that only cytokines correlating with ADMA levels can be regarded as potential predictors of end-organ damage in patients undergoing treatment against stage II EH and suffering from the pathology for 10-14 years. ADMA is a methylated analog of L-arginine (a substrate for NO synthesis) that competitively inhibits the functional activity of eNOS [16], curbing the NO synthesis and leading to its poor availability for vasorelaxation and vasoprotection [17]. This pathogenic pathway is important: the role of ADMA and SDMA in pathology is currently in the focus of scientific research. This study established that M-CSF was the only independent criterium (from the entire spectrum of the analyzed parameters) that had a high predictive value (even when compared to

Table 2. The relationship between changes in IL1ra, IL1 1 , IL6, TNFa, M-CSF, and IL10 concentrations measured at the beginning of the study AND the rate of complications $(95 \% \mathrm{Cl})$ during the 5 -year follow-up period in patients in treatment for long-settled $\mathrm{EH}$

\begin{tabular}{|c|c|c|c|c|}
\hline & Quartile I & Quartile II & Quartile III & Quartile VI \\
\hline & $n=50$ & $n=50$ & $n=50$ & $n=50$ \\
\hline IL1ra & $(330-511)$ & $(512-575)$ & $(574-633)$ & $(634-820)$ \\
\hline Complications (number of patients) & 18 & 9 & 10 & 10 \\
\hline \multirow[t]{2}{*}{ Absolute risk (\%) } & $\begin{array}{c}36 \\
{[22.7-49.3]}\end{array}$ & $\begin{array}{c}18 \\
{[7.35-28.6]}\end{array}$ & $\begin{array}{c}20 \\
{[8.91-31]}\end{array}$ & $\begin{array}{c}20 \\
{[8.91-31]}\end{array}$ \\
\hline & 36 [22.7-49.3] & \multicolumn{3}{|c|}{$19.3[13-25.6]$} \\
\hline Risk ratio & \multicolumn{4}{|c|}{ Quartiles I / II + III + IV: 1.86 [1.13-3.05] } \\
\hline IL1 $\beta$ & $(2.95-14.8)$ & $(14.9-8.7)$ & $(18.8-22.5)$ & $(22.6-34.4)$ \\
\hline Complications (number of patients) & 1 & 8 & 18 & 20 \\
\hline \multirow[t]{2}{*}{ Absolute risk (\%) } & \multirow{2}{*}{$\frac{2}{[2.43-4.43]}$} & \multirow{2}{*}{$\begin{array}{c}16 \\
{[5.84-26.2]}\end{array}$} & $\begin{array}{c}36 \\
{[22.7-49.3]}\end{array}$ & $\begin{array}{c}40 \\
{[26.4-53.6]}\end{array}$ \\
\hline & & & \multicolumn{2}{|c|}{$38[28.5-47.5]$} \\
\hline Risk ratio & \multicolumn{4}{|c|}{ Quartiles II / III + IV: $2.37[1.2-4.7]^{*}$} \\
\hline Risk ratio & \multicolumn{4}{|c|}{ Quartiles I / II + III + IV: 1.86 [1.13-3.05] ${ }^{*}$} \\
\hline IL6 & $(12.5-20.8)$ & $(20.9-23.7)$ & $(23.8-27.5)$ & $(27.6-36.4)$ \\
\hline Complications (number of patients) & 8 & 9 & 14 & 16 \\
\hline \multirow{2}{*}{ Absolute risk (\%) } & $16[5.8-26]$ & $18[7.35-28.6]$ & $28[15.6-40]$ & 32 [19-45] \\
\hline & \multicolumn{2}{|c|}{$17[8-22.1]$} & \multicolumn{2}{|c|}{30 [21-39] } \\
\hline Risk ratio & \multicolumn{4}{|c|}{ Quartiles I + II / III + IV: $1.76[1.04-2.99]^{*}$} \\
\hline TNFa & $(10.3-18.3)$ & $(18.6-23.7)$ & $(21.4-24)$ & $(24.1-32.4)$ \\
\hline Complications (number of patients) & 10 & 13 & 12 & 12 \\
\hline Absolute risk (\%) & 20 [8.9-31] & 26 [13.8-38] & $24[12.2-35.8]$ & 24 [12.2-35.8] \\
\hline Risk ratio & \multicolumn{2}{|c|}{ Quartiles I / II: 1.3 [0.63-2.69] } & \multicolumn{2}{|c|}{ Quartiles II / III + IV: 0.92 [1.04-1.65] } \\
\hline M-CSF & $(138-319)$ & $(320-388)$ & $(389-453)$ & $(454-640)$ \\
\hline Complications (number of patients) & 0 & 7 & 31 & 9 \\
\hline Absolute risk (\%) & 0 & $14[4.42-23.6]$ & $62[48.5-55.4]$ & $18[7.55-28.6]$ \\
\hline Risk ratio & \multicolumn{4}{|c|}{$\begin{array}{l}\text { Quartiles II + IV / III: } 3.87[2.35-6.38]^{*} \\
\text { Quartiles II/IV = 1.28 [0.52-3.18] }\end{array}$} \\
\hline IL10 & $(5.1-19.9)$ & $(20-26.2)$ & $(26.3-31.5)$ & $(31.6-47.5)$ \\
\hline Complications (number of patients) & 15 & 16 & 8 & 8 \\
\hline \multirow{2}{*}{ Absolute risk (\%) } & 30 [19-45] & $32[15.6-40]$ & 16 [5.84-26.2] & 16 [5.84-26.2] \\
\hline & \multicolumn{2}{|c|}{$31[22-40]$} & \multicolumn{2}{|c|}{16 [5.84-26.2] } \\
\hline Risk ratio & \multicolumn{4}{|c|}{ Quartiles I + II / III + IV: 1.94 [1.13-3.31] } \\
\hline
\end{tabular}

Note: ${ }^{*}-p<0.05$ for the comparison of absolute risks if the interval does not include 1.

Table 3. Correlations between IL1 $\beta$, IL 1ra, IL6, IL10, and M-CSF concentrations AND the rate of cardiovascular complications (95\% Cl) during the 5-year observation period in patients with stage II EH. The univariate Cox regression

\begin{tabular}{|l|c|c|c|c|}
\hline \multicolumn{1}{|c|}{ Variables } & Beta & Standard & $t$-value & Exponent Beta \\
\hline IL1 $\beta(>18.8 \mathrm{pg} / \mathrm{ml})$ & 1.99 & 0.35 & 5.68 & 2.37 \\
\hline IL1ra $(<511 \mathrm{pg} / \mathrm{ml})$ & 1.24 & 0.28 & 4.43 & 2.06 \\
\hline IL6 $(>23.8 \mathrm{pg} / \mathrm{ml})$ & 1.27 & 0.35 & 3.62 & 0.006 \\
\hline IL10 $(<26.3 \mathrm{pg} / \mathrm{ml})$ & 1.22 & 0.27 & 4.52 & 0.042 \\
\hline M-CSF $(389-453) \mathrm{pg} / \mathrm{ml}$ & 2.44 & 0.25 & 9.76 & 0.007 \\
\hline
\end{tabular}

Note: in our Cox regression models, Beta is a regression coefficient; Standard is a standard error of the regression coefficient; $t$-value is the $t$-statistic; Exponent Beta is the value of the relative risk indicating a connection with the range of changes in the analyzed factor; $p$ shows statistical significance. 
ADMA and classic risk factors) in the assessment of risks for developing ACVE, MI and TIA in patients undergoing treatment for stage II EH who had been suffering from this condition for 10 to 14 years. This confirms the priority of the cytokine in the M-CSF-ADMA correlational pathogenic model with a subsequent cascade of reactions causing progression of the pathology. Earlier, we published an article demonstrating a direct correlation between M-CSF concentrations > $453 \mathrm{pg} / \mathrm{ml}$ and the levels of VEGF-A in the peripheral blood, which was consistent with a significant increase in the myocardial collateral blood flow (coronary angiography) and might explain a low rate of $\mathrm{MI}$ in the studied cohort of patients [18], affecting the total risk for cardiovascular complications. M-CSF can activate MAP-kinases via the M-CSFR-1 receptor; the kinases play a key role in the production of VEGF-A by activating ERK, increasing the p38 and JNK promoter activity and stabilizing VEGF-A mRNA in a dose-dependent pattern [19].

\section{CONCLUSIONS}

The data yielded by this study prove that changes in the cytokine concentrations (IL1 $\beta>18.8 \mathrm{pg} / \mathrm{ml}$, IL $1 \mathrm{ra}<511 \mathrm{pg} / \mathrm{ml}$, IL6 $>23.8 \mathrm{pg} / \mathrm{ml}$, IL10 $<26.3 \mathrm{pg} / \mathrm{ml}$ ) measured in the peripheral blood of patients suffering from stage II EH for 10 to 14 years and undergoing antihypertensive treatment correlate with a 5-year rate of cardiovascular complications (MI, ACVE, TIA). Only M-CSF at concentrations between 389 and $453 \mathrm{pg} / \mathrm{ml}$ can be regarded as a predictor of cardiac and cerebrovascular

Table 4. A correlation matrix for the cytokines in the peripheral blood of patients in treatment for stage II EH and the vasoactive peptides measured in the same patients

\begin{tabular}{|c|c|c|c|c|c|c|c|c|c|c|c|c|c|}
\hline & IL37 & LIF & sLIFr & IGF-1 & IGFBP-1 & M-CSF & IL34 & VEGF-A & CX3CL1 & CXCL10 & TGF $\beta 1$ & IL17A & Erythropoietin \\
\hline AT II & $\begin{array}{c}-0.28 \\
p>0.05\end{array}$ & $\begin{array}{c}0.51 \\
p<0.05\end{array}$ & $\begin{array}{c}-0.36 \\
p>0.05\end{array}$ & $\begin{array}{c}0.23 \\
p>0.05\end{array}$ & $\begin{array}{c}0.23 \\
p>0.05\end{array}$ & $\begin{array}{c}0.34 \\
p>0.05\end{array}$ & $\begin{array}{c}0.24 \\
p>0.05\end{array}$ & $\begin{array}{c}0.29 \\
p>0.05\end{array}$ & $\begin{array}{c}0.12 \\
p>0.05\end{array}$ & $\begin{array}{c}0.31 \\
p>0.05\end{array}$ & $\begin{array}{c}0.23 \\
p>0.05\end{array}$ & $\begin{array}{c}0.21 \\
p>0.05\end{array}$ & $\begin{array}{c}0.23 \\
p>0.05\end{array}$ \\
\hline ET-1 & $\begin{array}{c}-0.41 \\
p>0.05\end{array}$ & $\begin{array}{c}0.31 \\
p>0.05\end{array}$ & $\begin{array}{c}0.28 \\
p>0.05\end{array}$ & $\begin{array}{c}0.21 \\
p>0.05\end{array}$ & $\begin{array}{c}0.22 \\
p>0.05\end{array}$ & $\begin{array}{c}0.43 \\
p>0.05\end{array}$ & $\begin{array}{c}0.21 \\
p>0.05\end{array}$ & $\begin{array}{c}0.42 \\
p>0.05\end{array}$ & $\begin{array}{c}0.27 \\
p>0.05\end{array}$ & $\begin{array}{c}0.35 \\
p>0.05\end{array}$ & $\begin{array}{c}0.31 \\
p>0.05\end{array}$ & $\begin{array}{c}0.23 \\
p>0.05\end{array}$ & $\begin{array}{c}0.32 \\
p>0.05\end{array}$ \\
\hline NO & $\begin{array}{c}0.69 \\
p<0.05\end{array}$ & $\begin{array}{c}0.42 \\
p>0.05\end{array}$ & $\begin{array}{c}0.41 \\
p>0.05\end{array}$ & $\begin{array}{c}0.23 \\
p>0.05\end{array}$ & $\begin{array}{c}0.18 \\
p>0.05\end{array}$ & $\begin{array}{c}0.32 \\
p>0.05\end{array}$ & $\begin{array}{c}0.31 \\
p>0.05\end{array}$ & $\begin{array}{c}0.34 \\
p>0.05\end{array}$ & $\begin{array}{c}0.31 \\
p>0.05\end{array}$ & $\begin{array}{c}0.39 \\
p>0.05\end{array}$ & $\begin{array}{c}0.48 \\
p>0.05\end{array}$ & $\begin{array}{c}0.21 \\
p>0.05\end{array}$ & $\begin{array}{c}0.23 \\
p>0.05\end{array}$ \\
\hline ADMA & $\begin{array}{c}-0.32 \\
p>0.05\end{array}$ & $\begin{array}{c}0.33 \\
p>0.05\end{array}$ & $\begin{array}{c}0.49 \\
p>0.05\end{array}$ & $\begin{array}{c}0.28 \\
p>0.05\end{array}$ & $\begin{array}{c}0.45 \\
p>0.05\end{array}$ & $\begin{array}{c}0.58 \\
p<0.05\end{array}$ & $\begin{array}{c}0.24 \\
p>0.05\end{array}$ & $\begin{array}{c}0.28 \\
p>0.05\end{array}$ & $\begin{array}{c}0.22 \\
p>0.05\end{array}$ & $\begin{array}{c}0.15 \\
p>0.05\end{array}$ & $\begin{array}{c}0.34 \\
p>0.05\end{array}$ & $\begin{array}{c}0.31 \\
p>0.05\end{array}$ & $\begin{array}{c}0.32 \\
p>0.05\end{array}$ \\
\hline SDMA & $\begin{array}{c}-0.78 \\
p<0.001\end{array}$ & $\begin{array}{c}0.28 \\
p>0.05\end{array}$ & $\begin{array}{c}0.45 \\
p>0.05\end{array}$ & $\begin{array}{c}0.38 \\
p>0.05\end{array}$ & $\begin{array}{c}0.27 \\
p>0.05\end{array}$ & $\begin{array}{c}0.52 \\
p<0.05\end{array}$ & $\begin{array}{c}0.41 \\
p>0.05\end{array}$ & $\begin{array}{c}0.31 \\
p>0.05\end{array}$ & $\begin{array}{c}0.52 \\
p<0.05\end{array}$ & $\begin{array}{c}0.5 \\
p<0.05\end{array}$ & $\begin{array}{c}0.26 \\
p>0.05\end{array}$ & $\begin{array}{c}0.31 \\
p>0.05\end{array}$ & $\begin{array}{c}0.21 \\
p>0.05\end{array}$ \\
\hline eNOS & $\begin{array}{c}0.32 \\
p>0.05\end{array}$ & $\begin{array}{c}0.38 \\
p>0.05\end{array}$ & $\begin{array}{c}-0.39 \\
p>0.05\end{array}$ & $\begin{array}{c}0.21 \\
p>0.05\end{array}$ & $\begin{array}{c}0.34 \\
p>0.05\end{array}$ & $\begin{array}{c}0.31 \\
p>0.05\end{array}$ & $\begin{array}{c}0.24 \\
p>0.05\end{array}$ & $\begin{array}{c}0.11 \\
p>0.05\end{array}$ & $\begin{array}{c}-0.18 \\
p>0.05\end{array}$ & $\begin{array}{c}-0.31 \\
p>0.05\end{array}$ & $\begin{array}{c}0.23 \\
p>0.05\end{array}$ & $\begin{array}{c}0.32 \\
p>0.05\end{array}$ & $\begin{array}{c}0.34 \\
p>0.05\end{array}$ \\
\hline iNOS & $\begin{array}{c}-0.41 \\
p>0.05\end{array}$ & $\begin{array}{c}0.28 \\
p>0.05\end{array}$ & $\begin{array}{c}0.45 \\
p>0.05\end{array}$ & $\begin{array}{c}0.34 \\
p>0.05\end{array}$ & $\begin{array}{c}0.38 \\
p>0.05\end{array}$ & $\begin{array}{c}0.17 \\
p>0.05\end{array}$ & $\begin{array}{c}0.21 \\
p>0.05\end{array}$ & $\begin{array}{c}0.21 \\
p>0.05\end{array}$ & $\begin{array}{c}0.69 \\
p<0.01\end{array}$ & $\begin{array}{c}0.71 \\
p<0.01\end{array}$ & $\begin{array}{c}0.34 \\
p>0.05\end{array}$ & $\begin{array}{c}0.21 \\
p>0.05\end{array}$ & $\begin{array}{c}0.21 \\
p>0.05\end{array}$ \\
\hline $\begin{array}{c}\text { NT- } \\
\text { proCNP }\end{array}$ & $\begin{array}{c}-0.27 \\
p>0.05\end{array}$ & $\begin{array}{c}0.41 \\
p>0.05\end{array}$ & $\begin{array}{c}-0.28 \\
p>0.05\end{array}$ & $\begin{array}{c}0.27 \\
p>0.05\end{array}$ & $\begin{array}{c}0.37 \\
p>0.05\end{array}$ & $\begin{array}{c}0.41 \\
p>0.05\end{array}$ & $\begin{array}{c}0.25 \\
p>0.05\end{array}$ & $\begin{array}{c}0.32 \\
p>0.05\end{array}$ & $\begin{array}{c}-0.31 \\
p>0.05\end{array}$ & $\begin{array}{c}-0.27 \\
p>0.05\end{array}$ & $\begin{array}{c}0.52 \\
p<0.05\end{array}$ & $\begin{array}{c}0.23 \\
p>0.05\end{array}$ & $\begin{array}{c}0.24 \\
p>0.05\end{array}$ \\
\hline $\begin{array}{c}\text { NT- } \\
\text { proBNP }\end{array}$ & $\begin{array}{c}-0.78 \\
p<0.01\end{array}$ & $\begin{array}{c}-0.65 \\
p<0.05\end{array}$ & $\begin{array}{c}0.31 \\
p>0.05\end{array}$ & $\begin{array}{c}0.31 \\
p>0.05\end{array}$ & $\begin{array}{c}0.24 \\
p>0.05\end{array}$ & $\begin{array}{c}0.45 \\
p>0.05\end{array}$ & $\begin{array}{c}0.18 \\
p>0.05\end{array}$ & $\begin{array}{c}0.34 \\
p>0.05\end{array}$ & $\begin{array}{c}0.21 \\
p>0.05\end{array}$ & $\begin{array}{c}0.2 \\
p>0.05\end{array}$ & $\begin{array}{c}0.33 \\
p>0.05\end{array}$ & $\begin{array}{c}0.27 \\
p>0.05\end{array}$ & $\begin{array}{c}0.12 \\
p>0.05\end{array}$ \\
\hline
\end{tabular}

Note: the data are presented as a coefficient of multiple correlation; the minus symbol indicates that the established correlation is negative; $p$ shows the significance of differences.

Table 5. A correlation matrix for the cytokines in the peripheral blood of patients in treatment for stage II EH and the vasoactive peptides measured in the same patients

\begin{tabular}{|c|c|c|c|c|c|c|c|c|c|c|c|c|c|c|c|}
\hline & IL1 $\beta$ & IL1 $\alpha$ & IL1ra & IL18 & IL18BP & IL6 & sIL6r & TNFa & sTNF-RI & sVCAM-1 & IL2 & IL8 & IL4 & IL10 & IFNy \\
\hline AT II & $\begin{array}{c}0.41 \\
p>0.05\end{array}$ & $\begin{array}{c}0.34 \\
p>0.05\end{array}$ & $\begin{array}{c}-0.19 \\
p>0.05\end{array}$ & $\begin{array}{c}0.41 \\
p>0.05\end{array}$ & $\begin{array}{c}-0.23 \\
p>0.05\end{array}$ & $\begin{array}{c}0.43 \\
p>0.05\end{array}$ & $\begin{array}{c}0.33 \\
p>0.05\end{array}$ & $\begin{array}{c}0.41 \\
p>0.05\end{array}$ & $\begin{array}{c}0.22 \\
p>0.05\end{array}$ & $\begin{array}{c}0.21 \\
p>0.05\end{array}$ & $\begin{array}{c}0.18 \\
p>0.05\end{array}$ & $\begin{array}{c}0.37 \\
p>0.05\end{array}$ & $\begin{array}{c}0.22 \\
p>0.05\end{array}$ & $\begin{array}{c}-0.62 \\
p<0.05\end{array}$ & $\begin{array}{c}0.16 \\
p>0.05\end{array}$ \\
\hline ET-1 & $\begin{array}{c}0.68 \\
p<0.05\end{array}$ & $\begin{array}{c}0.65 \\
p<0.05\end{array}$ & $\begin{array}{c}-0.62 \\
p<0.05\end{array}$ & $\begin{array}{c}0.34 \\
p>0.05\end{array}$ & $\begin{array}{c}-0.36 \\
p>0.05\end{array}$ & $\begin{array}{c}0.27 \\
p>0.05\end{array}$ & $\begin{array}{c}0.41 \\
p>0.05\end{array}$ & $\begin{array}{c}0.36 \\
p>0.05\end{array}$ & $\begin{array}{c}0.24 \\
p>0.05\end{array}$ & $\begin{array}{c}0.31 \\
p>0.05\end{array}$ & $\begin{array}{c}0.25 \\
p>0.05\end{array}$ & $\begin{array}{c}0.69 \\
p<0.01\end{array}$ & $\begin{array}{c}0.24 \\
p>0.05\end{array}$ & $\begin{array}{c}-0.36 \\
p>0.05\end{array}$ & $\begin{array}{c}0.18 \\
p>0.05\end{array}$ \\
\hline NO & $\begin{array}{c}0.64 \\
p<0.05\end{array}$ & $\begin{array}{c}0.46 \\
p>0.05\end{array}$ & $\begin{array}{c}0.49 \\
p<0.05\end{array}$ & $\begin{array}{c}-0.27 \\
p>0.05\end{array}$ & $\begin{array}{c}0.64 \\
p<0.05\end{array}$ & $\begin{array}{c}0.49 \\
p>0.05\end{array}$ & $\begin{array}{c}0.33 \\
p>0.05\end{array}$ & $\begin{array}{c}0.44 \\
p>0.05\end{array}$ & $\begin{array}{c}-0.38 \\
p>0.05\end{array}$ & $\begin{array}{c}0.25 \\
p>0.05\end{array}$ & $\begin{array}{c}0.37 \\
p>0.05\end{array}$ & $\begin{array}{c}-0.41 \\
p>0.05\end{array}$ & $\begin{array}{c}-0.38 \\
p>0.05\end{array}$ & $\begin{array}{c}0.33 \\
p>0.05\end{array}$ & $\begin{array}{c}0.41 \\
p>0.05\end{array}$ \\
\hline ADMA & $\begin{array}{c}0.52 \\
p<0.05\end{array}$ & $\begin{array}{c}0.4 \\
p>0.05\end{array}$ & $\begin{array}{c}-0.58 \\
p<0.05\end{array}$ & $\begin{array}{c}0.36 \\
p>0.05\end{array}$ & $\begin{array}{c}-0.41 \\
p>0.05\end{array}$ & $\begin{array}{c}0.57 \\
p<0.05\end{array}$ & $\begin{array}{c}0.25 \\
p>0.05\end{array}$ & $\begin{array}{c}0.38 \\
p>0.05\end{array}$ & $\begin{array}{c}0.31 \\
p>0.05\end{array}$ & $\begin{array}{c}0.38 \\
p>0.05\end{array}$ & $\begin{array}{c}0.33 \\
p>0.05\end{array}$ & $\begin{array}{c}0.27 \\
p>0.05\end{array}$ & $\begin{array}{c}0.31 \\
p>0.05\end{array}$ & $\begin{array}{c}-0.55 \\
p<0.05\end{array}$ & $\begin{array}{c}0.24 \\
p>0.05\end{array}$ \\
\hline SDMA & $\begin{array}{c}0.34 \\
p>0.05\end{array}$ & $\begin{array}{c}0.29 \\
p>0.05\end{array}$ & $\begin{array}{c}-0.16 \\
p>0.05\end{array}$ & $\begin{array}{c}0.48 \\
p>0.05\end{array}$ & $\begin{array}{c}-0.71 \\
p<0.01\end{array}$ & $\begin{array}{c}0.29 \\
p>0.05\end{array}$ & $\begin{array}{c}0.23 \\
p>0.05\end{array}$ & $\begin{array}{c}0.26 \\
p>0.05\end{array}$ & $\begin{array}{c}0.25 \\
p>0.05\end{array}$ & $\begin{array}{c}0.43 \\
p>0.05\end{array}$ & $\begin{array}{c}0.72 \\
p<0.01\end{array}$ & $\begin{array}{c}0.53 \\
p<0.05\end{array}$ & $\begin{array}{c}0.25 \\
p>0.05\end{array}$ & $\begin{array}{c}-0.23 \\
p>0.05\end{array}$ & $\begin{array}{c}0.58 \\
p<0.05\end{array}$ \\
\hline eNOS & $\begin{array}{c}-0.62 \\
p<0.05\end{array}$ & $\begin{array}{c}-0.67 \\
p<0.05\end{array}$ & $\begin{array}{c}0.51 \\
p<0.05\end{array}$ & $\begin{array}{c}0.22 \\
p>0.05\end{array}$ & $\begin{array}{c}0.37 \\
p>0.05\end{array}$ & $\begin{array}{c}-0.22 \\
p>0.05\end{array}$ & $\begin{array}{c}-0.35 \\
p>0.05\end{array}$ & $\begin{array}{c}0.4 \\
p>0.05\end{array}$ & $\begin{array}{c}0.27 \\
p>0.05\end{array}$ & $\begin{array}{c}0.31 \\
p>0.05\end{array}$ & $\begin{array}{c}-0.13 \\
p>0.05\end{array}$ & $\begin{array}{c}-0.31 \\
p>0.05\end{array}$ & $\begin{array}{c}0.27 \\
p>0.05\end{array}$ & $\begin{array}{c}0.46 \\
p>0.05\end{array}$ & $\begin{array}{c}-0.19 \\
p>0.05\end{array}$ \\
\hline iNOS & $\begin{array}{c}0.78 \\
p<0.01\end{array}$ & $\begin{array}{c}0.49 \\
p>0.05\end{array}$ & $\begin{array}{c}-0.12 \\
p>0.05\end{array}$ & $\begin{array}{c}0.36 \\
p>0.05\end{array}$ & $\begin{array}{c}-0.39 \\
p>0.05\end{array}$ & $\begin{array}{c}0.68 \\
p<0.05\end{array}$ & $\begin{array}{c}0.56 \\
p<0.05\end{array}$ & $\begin{array}{c}0.42 \\
p>0.05\end{array}$ & $\begin{array}{c}0.41 \\
p>0.05\end{array}$ & $\begin{array}{c}0.41 \\
p>0.05\end{array}$ & $\begin{array}{c}0.62 \\
p<0.05\end{array}$ & $\begin{array}{c}0.42 \\
p>0.05\end{array}$ & $\begin{array}{c}0.41 \\
p>0.05\end{array}$ & $\begin{array}{c}-0.4 \\
p>0.05\end{array}$ & $\begin{array}{c}0.52 \\
p<0.05\end{array}$ \\
\hline $\begin{array}{c}\text { NT- } \\
\text { proCNP }\end{array}$ & $\begin{array}{c}-0.58 \\
p<0.05\end{array}$ & $\begin{array}{c}0.68 \\
p<0.05\end{array}$ & $\begin{array}{c}0.13 \\
p>0.05\end{array}$ & $\begin{array}{c}0.31 \\
p>0.05\end{array}$ & $\begin{array}{c}-0.37 \\
p>0.05\end{array}$ & $\begin{array}{c}-0.61 \\
p<0.05\end{array}$ & $\begin{array}{c}0.24 \\
p>0.05\end{array}$ & $\begin{array}{c}0.52 \\
p<0.05\end{array}$ & $\begin{array}{c}0.39 \\
p>0.05\end{array}$ & $\begin{array}{c}0.24 \\
p>0.05\end{array}$ & $\begin{array}{c}-0.74 \\
p<0.01\end{array}$ & $\begin{array}{c}-0.37 \\
p>0.05\end{array}$ & $\begin{array}{c}0.39 \\
p>0.05\end{array}$ & $\begin{array}{c}0.29 \\
p>0.05\end{array}$ & $\begin{array}{c}-0.64 \\
p<0.05\end{array}$ \\
\hline $\begin{array}{c}\text { NT } \\
\text {-proBNP }\end{array}$ & $\begin{array}{c}0.47 \\
p>0.05\end{array}$ & $\begin{array}{c}0.29 \\
p>0.05\end{array}$ & $\begin{array}{c}-0.31 \\
p>0.05\end{array}$ & $\begin{array}{c}0.14 \\
p>0.05\end{array}$ & $\begin{array}{c}-0.73 \\
p<0.01\end{array}$ & $\begin{array}{c}0.17 \\
p>0.05\end{array}$ & $\begin{array}{c}-0.12 \\
p>0.05\end{array}$ & $\begin{array}{c}0.51 \\
p<0.05\end{array}$ & $\begin{array}{c}0.24 \\
p>0.05\end{array}$ & $\begin{array}{c}0.32 \\
p>0.05\end{array}$ & $\begin{array}{c}0.32 \\
p>0.05\end{array}$ & $\begin{array}{c}0.21 \\
p>0.05\end{array}$ & $\begin{array}{c}0.24 \\
p>0.05\end{array}$ & $\begin{array}{c}-0.22 \\
p>0.05\end{array}$ & $\begin{array}{c}0.32 \\
p>0.05\end{array}$ \\
\hline
\end{tabular}

Note: the data are presented as a coefficient of multiple correlation; the minus symbol indicates that the established correlation is negative; $p$ shows the significance of differences. 
Table 6. Correlations between IL1ß, IL1ra, IL6, IL10, M-CSF, ADMA concentrations and classic risk factors AND the rate of cardiovascular complications (95\% Cl) in a 5-year observation period in patients with stage II EH; the table shows the Cox regression model; the multivariate analysis was applied

\begin{tabular}{|c|c|c|c|c|c|}
\hline Variables & Beta & Standard & $t$-value & Exponent Beta & $p$ \\
\hline $\operatorname{IL} 1 \beta(>18.8 \mathrm{pg} / \mathrm{ml})$ & 1.19 & 0.73 & 1.63 & 2.05 & 0.058 \\
\hline IL1ra (< 511 pg/ml) & 1.04 & 0.62 & 1.67 & 1.34 & 0.067 \\
\hline IL6 (> $23.8 \mathrm{pg} / \mathrm{ml})$ & 1.07 & 0.63 & 1.69 & 2.17 & 0.062 \\
\hline IL10 (<26.3 pg/ml) & 1.06 & 0.66 & 1.61 & 1.32 & 0.072 \\
\hline M-CSF (389-453) pg/ml & 2.17 & 0.34 & 6.38 & 2.53 & 0.0007 \\
\hline ADMA $(>0.86 \mu \mathrm{mol} / \mathrm{l})$ & 1.49 & 0.77 & 1.93 & 2.09 & 0.068 \\
\hline Total cholesterol > $4.9 \mathrm{mmol} / \mathrm{l}$ & 1.18 & 0.73 & 1.62 & 1.63 & 0.062 \\
\hline $\mathrm{LDL}>3.0 \mathrm{mmol} / \mathrm{l}$ & 1.88 & 0.43 & 4.37 & 2.28 & 0.004 \\
\hline $\mathrm{HDL}$ in men $<1.0 \mathrm{mmol} / \mathrm{l}$ in women $<1.2 \mathrm{mmol} / \mathrm{l}$ & $1.12 / 1.19$ & $0.71 / 0.68$ & 1.58 & $1.38 / 1.32$ & $0.071 / 0.06$ \\
\hline
\end{tabular}

Note: in our Cox regression models, Beta is a regression coefficient; Standard is a standard error of the regression coefficient; $t$-value is the $t$-statistic; Exponent Beta is the value of the relative risk indicating a connection with the range of changes in the analyzed factor; $p$ shows statistical significance.

complications. Although the obtained data have a theoretical significance, M-CSF concentrations in the range from 389 to $453 \mathrm{pg} / \mathrm{ml}$ are a highly specific (81\%) but lowly sensitive (66\%) parameter in terms of predicting MI, ACVE and TIA in the studied cohort of patients. This means that an additional criterium should be added to the model to improve the diagnostic (prognostic) value of this cytokine. The role of patients' individual characteristics, such as genetic components including CSF1R TC/CA rs386693509: TC/CA variants in the established correlations should be further studied in patients with the progredient disease.

\section{References}

1. Wenzel U, Turner JE, Krebs C, et al. Immune Mechanisms in Arterial Hypertension. J Am Soc Nephrol. 2016; 27 (3): 677-86.

2. McMaster WG, Kirabo A, Madhur MS, Harrison DG. Inflammation immunity, and hypertensive end organ damage. Circ Res. 2015; 116 (6): 1022-33.

3. Bennardo M, Alibhai F, Tsimakouridze E, et al. Day-night dependence of gene expression and inflammatory responses in the remodeling murine heart post-myocardial. Am J Physiol Regul Integr Comp Physiol. 2016; 311 (6): 1243-54.

4. Ji Q, Cheng G, Ma N, et al. Circulating Th1, Th2, and Th17 Levels in Hypertensive Patients. Dis Markers 2017; (2017): 7146290. Available from: https://www.hindawi.com/journals/ dm/2017/7146290. PubMed PMID: 28757677.

5. Nosalski R, McGinnigle E, Siedlinski M, Guzik TJ. Novel Immune Mechanisms in Hypertension and Cardiovascular Risk. Current Cardiovascular Risk Reports. 2017; 11 (4): 12. Available from: https://www.researchgate.net/publication/314274524_Novel Immune_Mechanisms_in_Hypertension_and_Cardiovascular_Risk.

6. Rudemiller NP, Crowley SD. The role of chemokines in hypertension and consequent target organ damage. Pharmacological research. 2017; (119): 404-11.

7. Schwanekamp JA, Lorts A, Sargent MA, et al. TGFBI functions similar to periostin but is uniquely dispensable during cardiac injury. PLOS ONE. 2017; 12 (7). Available from: https://journals. plos.org/plosone/article?id=10.1371/journal. pone.0181945.

8. Wang $\mathrm{P}, \mathrm{He} \mathrm{Q}$, Liu C, et al. Functional polymorphism rs3783553 in the 3'-untranslated region of IL-1A increased the risk of ischemic stroke: A case-control study. Medicine. 2016; 96 (46). Available from: https://www.researchgate.net/publication/320348816_4-bp_ insertiondeletion_rs3783553_polymorphism_within_the_3aposUTR of_IL1A_contributes_to_the_risk_of_prostate_cancer_in_a_sample_ of_Iranian_Population.

9. Carlsson AC, Jansson JH, Söderberg S, et al. Levels of soluble tumor necrosis factor receptor 1 and 2, gender, and risk of myocardial infarction in Northern Sweden. Atherosclerosis. 2018; (272): 41-6.

\section{Литература}

1. Wenzel U, Turner JE, Krebs C, et al. Immune Mechanisms in Arterial Hypertension. J Am Soc Nephrol. 2016; 27 (3): 677-86.
10. Huang S, Frangogiannis NG. Anti-inflammatory therapies in myocardial infarction: failures, hopes and challenges. $\mathrm{Br} J$ Pharmacol. 2018; 175 (9): 1377-400.

11. Itani HA, Harrison DG. Memories that last in hypertension. Am J Physiol Renal Physiol. 2015; 308 (11): F1197-F1199. DOI: 10.1152/ajprenal.00633.2014.

12. Rucker JA, Crowley SD. The role of macrophages in hypertension and its complications Pflugers Arch. 2017; 469 (3-4): 419-30.

13. Hartman MHT, Groot HE, et al. Translational overview of cytokine inhibition in acute myocardial infarction and chronic heart failure. Trends Cardiovasc Med. 2018; 28 (6). DOI: 10.1016/j. tcm.2018.02.003. Available from: https://www.researchgate.net/ publication/260757993_Heart_Failure.

14. Jia D, Cai M, XiY, et al. Interval exercise training increases LIF expression and prevents myocardial infarction-induced skeletal muscle atrophy in rats. Life Sci. 2018; (193): 77-86.

15. Van der Heijden T, Bot I, Kuiper J. The IL-12 cytokine family in cardiovascular diseases. Cytokine. 2017; S1043-4666(17)303150. DOI: 10.1016/j.cyto.2017.10.010.

16. Papageorgiou N, Androulakis E, Papaioannou S, et al. Homoarginine in the shadow of asymmetric dimethylarginine: from nitric oxide to cardiovascular disease. Amino Acids. 2015; 47 (9): 1741-50.

17. Shin S, Thapa SK, Fung H-L. Cellular interactions between L-arginine and asymmetric dimethylarginine: Transport and metabolism. PLoS One. 2017; 12 (5): e0178710. DOI: 10.1371/ journal.pone.0178710.

18. Radaeva OA, Simbirtsev AS. M-CSF, IL-34, VEGF-A kak faktory riska razvitija infarkta miokarda, ostrogo narushenija mozgovogo krovoobrashhenija u bol'nyh jessencial'noj arterial'noj gipertenziej. Rossijskij immunologicheskij zhurnal. 2015; 9 (1): 93-101.

19. Lee $S$, Shi $X Q$, Fan $A$ et al. Targeting macrophage and microglia activation with colony stimulating factor 1 receptor inhibitor is an effective strategy to treat injury-triggered neuropathic pain. Mol Pain. 2018; (14): 1744806918764979. DOI: 10.1177/1744806918764979.

2. McMaster WG, Kirabo A, Madhur MS, Harrison DG. Inflammation, immunity, and hypertensive end organ damage. Circ Res. 2015; 
116 (6): 1022-33.

3. Bennardo M, Alibhai F, Tsimakouridze E, et al. Day-night dependence of gene expression and inflammatory responses in the remodeling murine heart post-myocardial. Am J Physiol Regul Integr Comp Physiol. 2016; 311 (6): 1243-54.

4. Ji Q, Cheng G, Ma N, et al. Circulating Th1, Th2, and Th17 Levels in Hypertensive Patients. Dis Markers 2017; (2017): 7146290. Available from: https://www.hindawi.com/journals/ dm/2017/7146290. PubMed PMID: 28757677.

5. Nosalski R, McGinnigle E, Siedlinski M, Guzik TJ. Novel Immune Mechanisms in Hypertension and Cardiovascular Risk. Current Cardiovascular Risk Reports. 2017; 11 (4): 12. Available from: https://www.researchgate.net/publication/314274524_Novel_ Immune_Mechanisms_in_Hypertension_and_Cardiovascular_Risk.

6. Rudemiller NP, Crowley SD. The role of chemokines in hypertension and consequent target organ damage. Pharmacological research. 2017; (119): 404-11.

7. Schwanekamp JA, Lorts A, Sargent MA, et al. TGFBI functions similar to periostin but is uniquely dispensable during cardiac injury. PLoS ONE. 2017; 12 (7). Available from: https://journals. plos.org/plosone/article?id=10.1371/journal.pone. 0181945 .

8. Wang $\mathrm{P}, \mathrm{He} \mathrm{Q}$, Liu C, et al. Functional polymorphism rs3783553 in the 3'-untranslated region of IL-1A increased the risk of ischemic stroke: A case-control study. Medicine. 2016; 96 (46). Available from: https://www.researchgate.net/publication/320348816_4-bp_ insertiondeletion_rs3783553_polymorphism_within_the_3aposUTR_ of_IL1A_contributes_to_the_risk_of_prostate_cancer_in_a_sample_ of_Iranian_Population.

9. Carlsson AC, Jansson JH, Söderberg S, et al. Levels of soluble tumor necrosis factor receptor 1 and 2, gender, and risk of myocardial infarction in Northern Sweden. Atherosclerosis. 2018; (272): 41-6.

10. Huang S, Frangogiannis NG. Anti-inflammatory therapies in myocardial infarction: failures, hopes and challenges. $\mathrm{Br} \mathrm{J}$ Pharmacol. 2018; 175 (9): 1377-400.
11. Itani HA, Harrison DG. Memories that last in hypertension. Am J Physiol Renal Physiol. 2015; 308 (11): F1197-F1199. DOI: 10.1152/ajprenal.00633.2014.

12. Rucker JA, Crowley SD. The role of macrophages in hypertension and its complications Pflugers Arch. 2017; 469 (3-4): 419-30.

13. Hartman MHT, Groot HE, et al. Translational overview of cytokine inhibition in acute myocardial infarction and chronic heart failure. Trends Cardiovasc Med. 2018; 28 (6). DOI: 10.1016/j. tcm.2018.02.003. Available from: https://www.researchgate. net/publication/260757993_Heart_Failure.

14. Jia D, Cai M, XiY, et al. Interval exercise training increases LIF expression and prevents myocardial infarction-induced skeletal muscle atrophy in rats. Life Sci. 2018; (193): 77-86.

15. Van der Heijden T, Bot I, Kuiper J. The IL-12 cytokine family in cardiovascular diseases. Cytokine. 2017; S1043-4666(17)303150. DOI: 10.1016/j.cyto.2017.10.010.

16. Papageorgiou N, Androulakis E, Papaioannou S, et al. Homoarginine in the shadow of asymmetric dimethylarginine: from nitric oxide to cardiovascular disease. Amino Acids. 2015; 47 (9): 1741-50.

17. Shin S, Thapa SK, Fung H-L. Cellular interactions between L-arginine and asymmetric dimethylarginine: Transport and metabolism. PLoS One. 2017; 12 (5): e0178710. DOI: 10.1371/ journal.pone.0178710.

18. Радаева О. А., Симбирцев А. C. M-CSF, IL-34, VEGF-A как факторы риска развития инфаркта миокарда, острого нарушения мозгового кровообращения у больных эссенциальной артериальной гипертензией. Российский иммунологический журнал. 2015; 9 (1): 93-101.

19. Lee $\mathrm{S}$, Shi $X Q$, Fan $A$ et al. Targeting macrophage and microglia activation with colony stimulating factor 1 receptor inhibitor is an effective strategy to treat injury-triggered neuropathic pain. Mol Pain. 2018; (14): 1744806918764979. DOI: $10.1177 / 1744806918764979$. 